\title{
Extreme temperature days and their potential impacts on southern Europe
}

\author{
A. Cardil ${ }^{1}$, D. M. Molina ${ }^{1}$, and L. N. Kobziar ${ }^{2}$ \\ ${ }^{1}$ School of Agrifood and Forestry Science and Engineering, University of Lleida, Avenida Rovira Roure 191, \\ 25198 Lleida, Spain \\ ${ }^{2}$ School of Forest Resources and Conservation, University of Florida, P.O. Box 110410, Gainesville, 32611-0410, USA \\ Correspondence to: A. Cardil (adriancardil@gmail.com)
}

Received: 28 April 2014 - Published in Nat. Hazards Earth Syst. Sci. Discuss.: 2 June 2014

Revised: 30 August 2014 - Accepted: 14 October 2014 - Published: 19 November 2014

\begin{abstract}
Extreme-temperature events have consequences for human health and mortality, forest disturbance patterns, agricultural productivity, and the economic repercussions of these consequences combined. To gain insight into whether extreme-temperature events are changing in light of global climate dynamics, the annual numbers of high-temperature days (those with temperatures higher than $20,22.5$, and $25^{\circ} \mathrm{C}$ at $850 \mathrm{hPa}$ ) were analyzed across southern Europe from the years 1978 to 2012. A significant increase in the frequency of these days was found in many areas over the time period analyzed, and patterns in the spatial distribution of these changes were identified. We discuss the potential consequences of the increases in high-temperature days with regards to forest fire risk, human health, agriculture, energy demands, and some potential economic repercussions.
\end{abstract}

\section{Introduction}

Heat-wave events play a role in determining human health and episodic mortality patterns, and are also recognized as having marked impacts on agriculture, forestry, wildland fire, and socioeconomic activities (Poumadère et al., 2005; Mills, 2005; Trigo et al., 2006; Kuglitsch et al., 2010; Cardil et al., 2013). Multiple heat waves have been recorded in southern Europe in recent years, including in 2003, when summer temperatures across Europe were very likely warmer than any other summer looking back to 1500 (Luterbacher et al., 2004). Extreme-temperature days and heat waves were linked to above-average human mortality in the cities of Madrid and Lisbon (García-Herrera et al., 2005), and in
France in 2003 (Poumadere et al., 2005). In addition, large wildland fires are more likely during heat-wave events, burning thousands of hectares across multiple ecosystems in the Mediterranean region (e.g., 1994 in Spain, 2003 in Portugal, 2007 in Greece). In Russia in 2010, unusual temperatures around $40^{\circ} \mathrm{C}$ were recorded and the resulting drought was linked to wildfires that were responsible for hundreds of human deaths, covering much of the region with toxic smog (Gobin et al., 2013). An unprecedented spring heat wave in the USA and Canada peaked in intensity during March of 2012 (Gobin et al., 2013), followed by a summer of destructive and even fatal wildfires in North American forests.

Extreme-temperature events can also exacerbate other effects of global climate change. For example, climate-changerelated increases in average temperatures have been linked to widespread insect outbreaks in North American forests (Safranyik, 2004), which, coupled with wildfires propagated by extreme-temperature events, can have an multiplied effect on forest persistence. The synergistic effects of extreme temperatures and their repercussions have been identified as possible mechanisms for the development of a positive feedback cycle of global warming and continued loss of greenhouse gases to the atmosphere.

Climate-change projections for the Mediterranean Basin show a higher variability in weather conditions and an increase in extreme weather events, with longer, more frequent, and even more intense heat waves (Moriondo et al., 2006; Diffenbaugh et al., 2007; Giorgi and Lionello, 2008; Regato, 2008; Giannakopoulos et al., 2009; Barriopedro et al., 2011). The Mediterranean is widely considered a climatechange "hot spot" (Giorgi, 2006), meaning that the region is a 


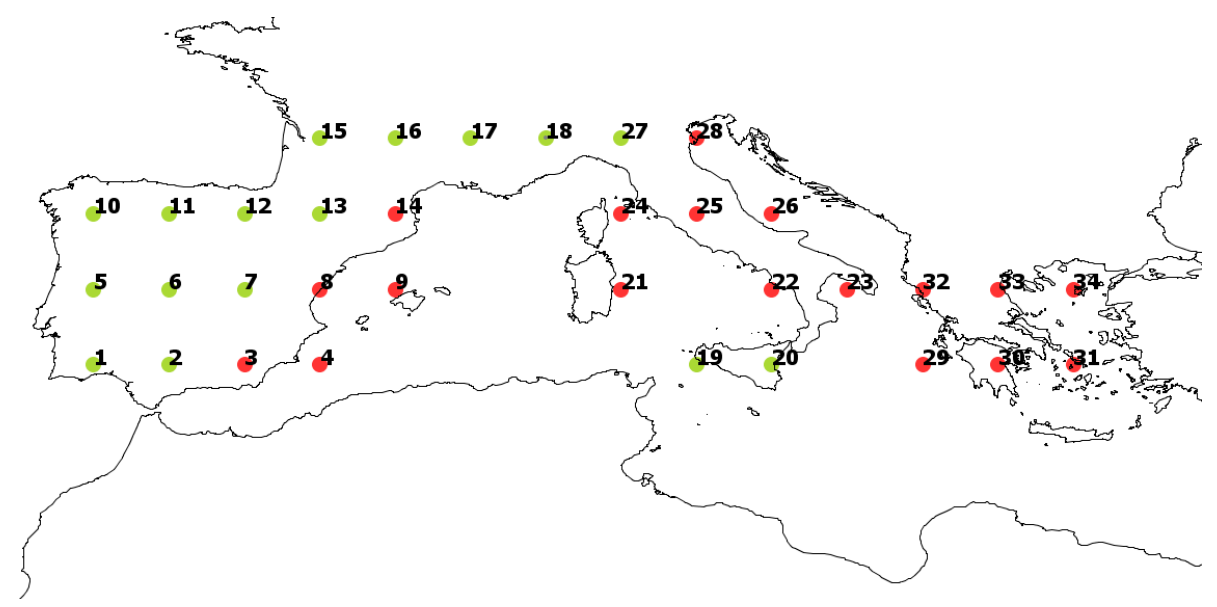

Figure 1. Identification of the National Center for Environmental Prediction (NCEP) reanalysis analyzed points in the study area (Portugal, Spain, the south of France, Italy, and Greece). Red points mean a significant increase ( $p$ value $<0.05)$ in the annual number of days with an air temperature higher than $20^{\circ} \mathrm{C}$ at $850 \mathrm{hPa}\left(\mathrm{HTD}_{20}\right)$ in the June-September period from 1978 to 2012. Green points mean that there were no significant changes in terms of annual number of $\mathrm{HTD}_{20}$.

sensitiveindicator of changes that have already occurred, and it is expected to be a sensitive responder to predicted changes due to its location at the intersection of tropical and midlatitude atmospheric and oceanographic processes. Although numerous authors have explored the relationships between predicted climate change and expected increases in temperatures (e.g., Giorgi and Lionello, 2008; Giannakopoulos et al., 2009), few have identified spatial patterns and differences in magnitude of recent changes in extreme-temperature-day frequencies. In order to explore trends in extreme-temperature events over time across southern Europe, we analyzed (i) annual number of high-temperature days and their spatial distribution, and (ii) temporal trends of extreme-temperature events to identify and quantify significant changes over the 1978-2012 period.

Although extreme events can be interpreted using a variety of metrics, we focused on air temperature at $850 \mathrm{hPa}$ as a reference - the air temperature at approximately $1500 \mathrm{~m}$ a.s.l. (above sea level) where pressure is $850 \mathrm{hPa}-$ because it is used by many forecast agencies and is an indicator of heat waves or the evolution of temperatures in successive days (AEMET - Spanish Meteorological Agency; Trigo et al., 2006). In addition, some problems that affect near-surface reanalysis do not occur when using temperatures at this altitude (Ogi et al., 2005). We assessed trends in the number of high-temperature days (HTDs) with three different temperature thresholds: $20,22.5$, and $25^{\circ} \mathrm{C}$. Because the 95th percentile weather, or the "hot tail", has been identified as an important metric for predicting future heat stress and amplification by soil moisture loss in the Mediterranean Basin (Diffenbaugh et al., 2007), we also analyzed this variable using the summer period (June-September) from 1978 to 2012 .

\section{Methods}

\subsection{Study area}

This work focused on southern Europe because it is expected to be the most susceptible European area to a significant increase in extreme-temperature events and to sustain some of the most significant impacts (Giorgi, 2006; Giannakopoulos et al., 2009). In all, 34 points were used for the analysis, distributed systematically across the region (Fig. 1). This region comprises Portugal, Spain (Mediterranean Coast, points 2, 3, 4, 8, 9, and 14; interior Spain, points 6, 7, and 13; northern Spain, points 10,11, and 12) the south of France, Italy (Italian Peninsula, points 22, 23, 25, 26, 27, and 28; Italian islands, points 19, 20, and 21), and Greece. These points were chosen in order to capture a representation of trends for all of southern Europe below the 45th parallel.

\subsection{High-temperature days (HTDs)}

We used reanalysis data from the National Centers for Environmental Prediction (NCEP) and the National Center for Atmospheric Research (Kalnay et al., 1996) to characterize the high-temperature days on a synoptic scale. NCEP output data have a horizontal resolution of $2.5^{\circ}$ latitude-longitude. We analyzed the 34 points distributed in the study area, as shown in Fig. 1. Daily air temperature data at $850 \mathrm{hPa}$ pressure level at 00:00 UTC were analyzed from 1978 to 2012. We chose the air temperature at $850 \mathrm{hPa}$ as a reference because it is used by Meteorological Services to forecast and display heat waves or the trend of temperatures in successive days (AEMET). It is also used by different agencies across southern Europe (i.e., Aragón Forest Service, CastillaLa-Mancha Forest Service, Catalonia Fire-Fighting Service, Valencia Fire-Fighting Service, CFVA in Sardinia, Italy) to 
analyze past fire weather events and to forecast daily potential fire occurrence and behavior (Trigo et al., 2006; GarciaOrtega et al., 2011). In this manner, it provides adequate regional coverage and it is representative of the surface, avoiding some of the problems that affect near-surface reanalysis (Ogi et al., 2005; Trigo et al., 2005, 2006).

We used several HTD categories considering different temperature thresholds. (1) $\mathrm{HTD}_{20}$ : the days with an air temperature higher than $20^{\circ} \mathrm{C}$ at $850 \mathrm{hPa}$; (2) $\mathrm{HTD}_{22.5}$ : the days with an air temperature higher than $22.5^{\circ} \mathrm{C}$ at $850 \mathrm{hPa}$; (3) $\mathrm{HTD}_{25}$ : the days with an air temperature higher than $25^{\circ} \mathrm{C}$ at $850 \mathrm{hPa}$; (4) $\mathrm{HTD}_{\mathrm{p} 95}$ : the 95th percentile of air temperature at $850 \mathrm{hPa}$ in the June-September period from 1978 to 2012 . The use of the $95 \%$ percentile helps capture the different implications for human health, energy systems, and natural vegetation and disturbances for temperature extremes in different locations. For example, in the northern section of the study area, where mean temperatures are generally lower, a temperature above $20^{\circ} \mathrm{C}$ would exceed the 95th percentile, while the same temperature would be nearly 5 degrees below the 95 th percentile at the southern latitudes.

The limit of $20^{\circ} \mathrm{C}$ of air temperature at $850 \mathrm{hPa}$ was chosen because it provides high temperatures in surface and typically low relative humidity in the territory, and is associated with heat waves in many zones in the study area (Montserrat, 1998; Cardil et al., 2013). We analyzed temporal trends in relation to the annual number of HTDs in all four categories using least squares fitted linear regression models and tested whether slopes differed significantly from $0(p<0.05)$. For the locations in which significant temporal changes were found to exist, we further investigated spatial patterns of change. To determine whether significant differences in number and changes in high-temperature days across latitudes and longitudes, we used a one-way "analysis of variance" (ANOVA) followed by Tukey's "honestly significant difference" (HSD) test.

\section{Results}

The annual number of HTDs differed in relation to the different areas and countries. Generally, points with higher latitude had fewer HTDs in all categories (Fig. 2). The points with a higher annual number of $\mathrm{HTD}_{20}, \mathrm{HTD}_{22.5}$, and $\mathrm{HTD}_{25}$ are located on Spanish Mediterranean Coast (points 2, 3, and 4) and in the south of Portugal (point 1; Fig. 2). However, points located in Greece at the same latitude had a significantly lower number of these days. The island of Sardinia (point 21) and the Balearic Islands (point 9) had higher numbers of extreme-temperature days in relation to other locations at the same latitude. The same results were obtained in relation to the 95th percentile in terms of temperature during the June-September period from 1978 to 2012.

Temporal trends in terms of annual number of $\mathrm{HTD}_{\mathrm{p} 95}$, $\mathrm{HTD}_{20}, \mathrm{HTD}_{22.5}$, and the 95th percentile for all analyzed points are shown in Table 1 and Fig. 3. Note that the $\mathrm{HTD}_{25}$ category is not in Table 1 because no significant trends were found at any point, mainly due to the low number of these days. A significant increase in the annual number of $\mathrm{HTD}_{20}$ was found in locations around the Spanish Mediterranean Coast (Fig. 1 and Table 1). However, in other parts of Spain and Portugal, the annual number of HTDs did not change in any analyzed temperature threshold. In the south of France, no significant changes over the study time period analyzed were detected. However, significant increases in the annual number of $\mathrm{HTD}_{20}$ and/or the 95th percentile were found in the majority of sites in Italy and Greece (except in Sicily). Extreme weather days are becoming more frequent in these areas. Additionally, the highest increases in terms of annual number of $\mathrm{HTD}_{20}$ were found in Greece and along the Spanish Mediterranean Coast $\left(0.60 \mathrm{HTD}_{20}\right.$ more per year over the entire period). In Italy, significant increases were found, but they were lower than those in Greece or along the Spanish Mediterranean Coast $\left(0.35 \mathrm{HTD}_{20}\right.$ more per year).

When all sites were considered, $\mathrm{HTD}_{20}$ was higher overall in coastal vs. inland locations ( 8.8 vs. 5.1 days increase in days over time; $p=0.005)$. Percentage change in $\mathrm{HTD}_{25}$ differed between locations, being negative along the coast $(-4.4 \%)$ and positive inland $(+41.6 \%, p<0.05)$. Other differences associated with proximity to the Mediterranean Coast were not detected. Although significant primarily for political planning, some overall differences among countries were detected. Italy had a higher change in $\mathrm{HTD}_{95}$ than Spain (4.1 vs. 2.3 days, $p<0.05$ ), and Spain had a greater relative change in $\mathrm{HTD}_{25}$ than Italy $(43.3 \%$ vs. $-25.9 \%, p<0.05)$. Greece had more than three times the increase in $\mathrm{HTD}_{20}$ than France (9.6 vs. 2.3 days, $p<0.05$ ). Regarding HTD $_{22.5}$, there is a difference among northern locations (points 14 and 28) vs. southern locations (3, 4, 22, and 23) in Spain and Italy. The southern locations displayed a significant increase (0.3 $\mathrm{HTD}_{22.5}$ more per year) in the number of $\mathrm{HTD}_{22.5}$.

At higher latitudes, the increase in the number of days with an air temperature at $850 \mathrm{hPa}$ higher than 20 and $22.5^{\circ} \mathrm{C}$ was less than that at lower latitudes (Fig. 4). However, the relative increase in $\mathrm{HTD}_{20}$ was significantly larger at higher latitudes (Fig. 5), considering only sites where significant temporal changes were evidenced. However, considering 22.5 and $25^{\circ} \mathrm{C}$ thresholds, the relative increase in HTDs did not change consistently with latitude. In relation to the days that exceeded the 95th percentile, at higher latitudes there was an increase in both number of days and relative increase in number of days (Figs. 4 and 5). In most points included within the study scope, there was an increase in both the number of days in $\mathrm{HTD}_{20}, \mathrm{HTD}_{22.5}$, and the 95th percentile and the relative increase in these categories from 1978-1987 to 2002-2012. The highest relative increases were found in Italy and Greece, with values higher than $100 \%$; in other words, more than a doubling in the number of days (Table 2). 

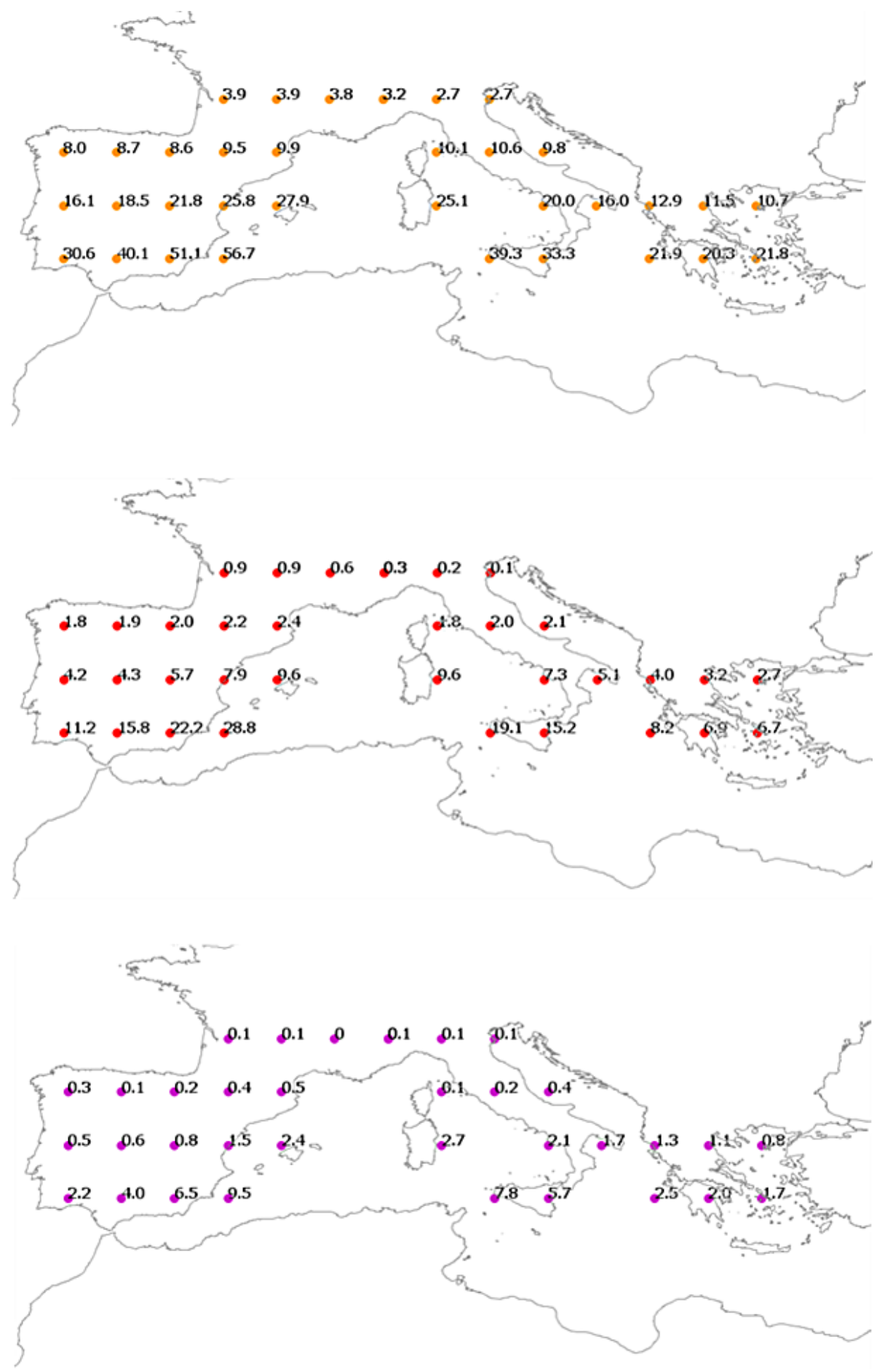

Figure 2. Mean annual number of days with an air temperature higher than $20^{\circ} \mathrm{C}$ (orange points), $22.5^{\circ} \mathrm{C}$ (red points), and $25^{\circ} \mathrm{C}$ (purple points) at $850 \mathrm{hPa}$ in the June-September period from 1978 to 2012.

\section{Discussion}

Mean, maximum, and minimum temperatures have increased and will likely continue to increase in southern Europe in the future (Moriondo et al., 2006; IPCC, 2007; Giorgi and
Lionello, 2008; Giannakopoulos et al., 2009). Our study showed that there was also a trend towards more frequent HTDs in the summer (June to September) in Mediterranean coastal areas and at more southerly latitudes across the study area. This is in agreement with other studies on temperature 
Table 1. Simple linear regression analysis of significant trends in annual number of $\mathrm{HTD}_{\mathrm{p} 95}, \mathrm{HTD}_{20}$, and $\mathrm{HTD}_{22.5}$ over time in the study area during the June-September period from 1978 to 2012. Point locations are mapped in Fig. 1.

\begin{tabular}{|c|c|c|c|c|c|}
\hline \multirow[t]{2}{*}{ Point } & \multirow{2}{*}{$\begin{array}{l}\text { Latitude/ } \\
\text { longitude }\end{array}$} & \multirow[t]{2}{*}{ Country } & \multicolumn{3}{|c|}{ ( $p$ values) and/slope coefficients } \\
\hline & & & $\mathrm{HTD}_{20}$ & $\mathrm{HTD}_{22.5}$ & $\mathrm{HTD}_{\mathrm{p} 95}$ \\
\hline 1 & $37.5^{\circ} / 352.5^{\circ}$ & Portugal & n.s. $(0.480) / \mathbf{0 . 1 1 1}$ & n.s. $(0.090) / \mathbf{0 . 1 5 6}$ & n.s. $(0.370) / \mathbf{0 . 0 5 7}$ \\
\hline 2 & $37.5^{\circ} / 355^{\circ}$ & Spain & n.s. $(0.107) / \mathbf{0 . 2 9 5}$ & n.s. $(0.083) / \mathbf{0 . 1 9 9}$ & n.s. $(0.646) / \mathbf{0 . 0 3 1}$ \\
\hline 3 & $37.5^{\circ} / 357.5^{\circ}$ & Spain & $+(0.009) / \mathbf{0 . 5 2 5}$ & $+(0.029) / \mathbf{0 . 3 4 4}$ & n.s. $(0.182) / \mathbf{0 . 1 0 3}$ \\
\hline 4 & $37.5^{\circ} / 0^{\circ}$ & Spain & $+(0.008) / \mathbf{0 . 5 3 1}$ & $+(0.002) / \mathbf{0 . 5 4 5}$ & n.s. $(0.084) / \mathbf{0 . 1 4 2}$ \\
\hline 5 & $40^{\circ} / 352.5^{\circ}$ & Portugal & n.s. $(0.354) / \mathbf{0 . 1 1 8}$ & n.s. $(0.375) / \mathbf{0 . 0 5 4}$ & n.s. $(0.552) / \mathbf{0 . 0 4 8}$ \\
\hline 6 & $40^{\circ} / 355^{\circ}$ & Spain & n.s. $(0.296) / \mathbf{0 . 1 1 5}$ & n.s. $(0.836) /-\mathbf{0 . 0 1 2}$ & n.s. $(0.651) / \mathbf{0 . 0 2 8}$ \\
\hline 7 & $40^{\circ} / 357.5^{\circ}$ & Spain & n.s. $(0.072) / \mathbf{0 . 2 4 8}$ & n.s. $(0.884) / \mathbf{0 . 0 0 9}$ & n.s. $(0.893) / \mathbf{0 . 0 0 8}$ \\
\hline 8 & $40^{\circ} / 0^{\circ}$ & Spain & $+(0.003) / \mathbf{0 . 4 8 4}$ & n.s. $(0.173) / \mathbf{0 . 1 1 8}$ & n.s. $(0.278) / \mathbf{0 . 0 8 4}$ \\
\hline 9 & $40^{\circ} / 2.5^{\circ}$ & Spain & $+(0.001) / \mathbf{0 . 6 0 0}$ & $+(0.018) / \mathbf{0 . 2 2 2}$ & n.s. $(0.238) / \mathbf{0 . 0 9 4}$ \\
\hline 10 & $42.5^{\circ} / 352.5^{\circ}$ & Spain & n.s. $(0.870) / \mathbf{0 . 0 1 5}$ & n.s. $(0.963) / \mathbf{0 . 0 0 2}$ & n.s. $(0.878) / \mathbf{0 . 0 1 1}$ \\
\hline 11 & $42.5^{\circ} / 355^{\circ}$ & Spain & n.s. $(0.710) / \mathbf{0 . 0 3 2}$ & n.s. $(0.805) / \mathbf{0 . 0 1 1}$ & n.s. $(0.684) / \mathbf{0 . 0 3 2}$ \\
\hline 12 & $42.5^{\circ} / 357.5^{\circ}$ & Spain & n.s. $(0.273) / \mathbf{0 . 0 9 2}$ & n.s. $(0.550) / \mathbf{0 . 0 2 0}$ & n.s. $(0.381) / \mathbf{0 . 0 6 7}$ \\
\hline 13 & $42.5^{\circ} / 0^{\circ}$ & Spain & n.s. $(0.078) / \mathbf{0 . 1 4 7}$ & n.s. $(0.251) / \mathbf{0 . 0 3 8}$ & $+(0.044) / \mathbf{0 . 1 3 9}$ \\
\hline 14 & $42.5^{\circ} / 2.5^{\circ}$ & Spain & $+(0.010) / \mathbf{0 . 2 4 6}$ & n.s. $(0.486) / \mathbf{0 . 0 2 5}$ & n.s. $(0.058) / \mathbf{0 . 1 3 1}$ \\
\hline 15 & $45^{\circ} / 0^{\circ}$ & France & n.s. $(0.305) / \mathbf{0 . 0 5 1}$ & n.s. $(0.301) / \mathbf{0 . 0 3 1}$ & n.s. $(0.319) / \mathbf{0 . 0 7 7}$ \\
\hline 16 & $45^{\circ} / 2.5^{\circ}$ & France & n.s. $(0.159) / \mathbf{0 . 0 8 5}$ & n.s. $(0.178) / \mathbf{0 . 0 3 7}$ & n.s. $(0.081) / \mathbf{0 . 1 4 2}$ \\
\hline 17 & $45^{\circ} / 5^{\circ}$ & France & n.s. $(0.108) / \mathbf{0 . 1 1 5}$ & n.s. $(0.297) / \mathbf{0 . 0 2 2}$ & n.s. $(0.114) / \mathbf{0 . 1 3 5}$ \\
\hline 18 & $45^{\circ} / 7.5^{\circ}$ & France & n.s. $(0.111) / \mathbf{0 . 1 0 2}$ & n.s. $(0.240) / \mathbf{0 . 1 4 6}$ & $+(0.044) / \mathbf{0 . 1 6 7}$ \\
\hline 19 & $37.5^{\circ} / 12.5^{\circ}$ & Italy & n.s. $(0.181) / \mathbf{0 . 2 1 9}$ & n.s. $(0.179) / \mathbf{0 . 1 5 4}$ & n.s. $(0.513) / \mathbf{0 . 0 5 4}$ \\
\hline 20 & $37.5^{\circ} / 15^{\circ}$ & Italy & n.s. $(0.166) / \mathbf{0 . 2 2 2}$ & n.s. $(0.051) / \mathbf{0 . 1 8 6}$ & n.s. $(0.369) / \mathbf{0 . 0 7 3}$ \\
\hline 21 & $40^{\circ} / 10^{\circ}$ & Italy & $+(0.022) / \mathbf{0 . 3 7 1}$ & $+(0.032) / \mathbf{0 . 1 8 3}$ & n.s. $(0.096) / \mathbf{0 . 1 2 5}$ \\
\hline 22 & $40^{\circ} / 15^{\circ}$ & Italy & $+(0.014) / \mathbf{0 . 3 5 4}$ & $+(0.014) / \mathbf{0 . 1 8 2}$ & $+(0.014) / \mathbf{0 . 2 0 0}$ \\
\hline 23 & $40^{\circ} / 17.5^{\circ}$ & Italy & $+(0.006) / \mathbf{0 . 3 7 4}$ & n.s. $(0.978) /-\mathbf{0 . 0 0 1}$ & $+(0.019) / \mathbf{0 . 1 9 0}$ \\
\hline 24 & $42.5^{\circ} / 10^{\circ}$ & Italy & $+(0.011) / \mathbf{0 . 2 7 8}$ & n.s. $(0.459) / \mathbf{0 . 0 2 3}$ & $+(0.032) / \mathbf{0 . 2 0 0}$ \\
\hline 25 & $42.5^{\circ} / 12.5^{\circ}$ & Italy & $+(0.003) / \mathbf{0 . 3 5 4}$ & $+(0.047) / \mathbf{0 . 0 9 0}$ & $+(0.014) / \mathbf{0 . 2 1 1}$ \\
\hline 26 & $42.5^{\circ} / 15^{\circ}$ & Italy & $+(0.002) / \mathbf{0 . 3 5 3}$ & n.s. $(0.452) /-\mathbf{0 . 0 0 8}$ & $+(0.005) / \mathbf{0 . 2 1 3}$ \\
\hline 27 & $45^{\circ} / 10^{\circ}$ & Italy & n.s. $(0.080) / \mathbf{0 . 0 8 8}$ & n.s. $(0.610) /-\mathbf{0 . 0 0 8}$ & $+(0.013) / \mathbf{0 . 2 4 0}$ \\
\hline 28 & $45^{\circ} / 12.5^{\circ}$ & Italy & $+(0.038) / \mathbf{0 . 0 9 7}$ & n.s. $(0.353) /-\mathbf{0 . 0 0 9}$ & $+(0.023) / \mathbf{0 . 1 9 8}$ \\
\hline 29 & $37.5^{\circ} / 20^{\circ}$ & Greece & $+(0.011) / \mathbf{0 . 3 6 2}$ & n.s. $(0.065) / \mathbf{0 . 1 6 0}$ & n.s. $(0.169) / \mathbf{0 . 0 9 7}$ \\
\hline 30 & $37.5^{\circ} / 22.5^{\circ}$ & Greece & $+(0.003) / \mathbf{0 . 4 4 7}$ & n.s. $(0.060) / \mathbf{0 . 1 3 0}$ & n.s. $(0.052) / \mathbf{0 . 1 2 5}$ \\
\hline 31 & $37.5^{\circ} / 25^{\circ}$ & Greece & $+(<0.001) / \mathbf{0 . 6 0 5}$ & $+(0.025) / \mathbf{0 . 1 6 8}$ & $+(0.009) / \mathbf{0 . 1 6 5}$ \\
\hline 32 & $40^{\circ} / 20^{\circ}$ & Greece & $+(0.001) / \mathbf{0 . 4 3 1}$ & $+(0.032) / \mathbf{0 . 1 5 3}$ & $+(0.005) / \mathbf{0 . 2 3 1}$ \\
\hline 33 & $40^{\circ} / 22.5^{\circ}$ & Greece & $+(<0.001) / \mathbf{0 . 4 4 9}$ & n.s. $(0.081) / \mathbf{0 . 1 0 8}$ & $+(0.010) / \mathbf{0 . 2 2 3}$ \\
\hline 34 & $40^{\circ} / 25^{\circ}$ & Greece & $+(0.001) / \mathbf{0 . 4 1 3}$ & n.s. $(0.078) / \mathbf{0 . 0 8 7}$ & $+(0.012) / \mathbf{0 . 2 1 8}$ \\
\hline
\end{tabular}

+ Significant increase over time $(p$ value $<0.05)$, n.s. not significant trend $(p$ value $<0.05)$ and value in parenthesis means the $p$ value in the analyzed trend. The slope of the regression line is also shown in bold.

trends, which have been shown to be correlated to wildfire size and occurrence (Cardil et al., 2013, 2014). Overall, in southern Europe, most high-temperature days are related to the weather system that brings hot, dry air masses from North Africa (Rodriguez-Puebla et al., 2010; Pereira et al., 2011). However, we did not find the same HTD trends in NW Iberia, where other reports have documented increased warming of surface temperatures from 1974 to 2006 (Gómez-Gesteira et al., 2011), or in interior Spain. It is plausible that air fluxes from North Africa do not reach this area as frequently as they do in other regions, or that their influence is mitigated by other weather systems associated with Atlantic currents. Some HTDs might simply be caused by summer heating in central Spain (Spanish Plateau, $800 \mathrm{~m}$ a.s.1.).
Areas with the highest increases in terms of the annual number of $\mathrm{HTD}_{20}$ (June-September period) were found both in Greece and along the Spanish Mediterranean Coast. These areas are likely to be especially susceptible to the variety of impacts associated with heat-wave episodes, including ecological, social, and economic impacts. While higher-latitude (more northern) sites exhibited a smaller increase in the number of days with $\mathrm{HTD}_{22.5}$ and $\mathrm{HTD}_{20}$ than lower latitudes, the number of days exceeding the 95th percentile increased with increasing latitude. This finding is corroborated by the higher relative increase in HTD 95 and $\mathrm{HTD}_{20}$ with latitude. It may be that the affected vegetative, social, and economic systems at the lower-latitude sites have already experienced some of the pressures of adapting to, or mitigating, 


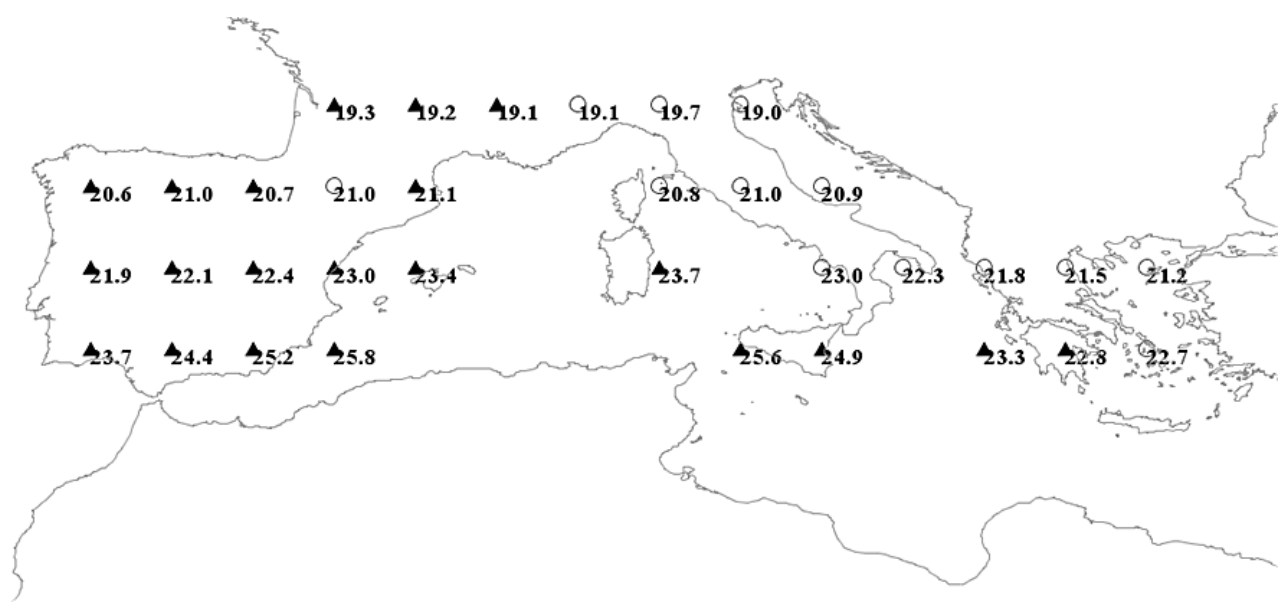

Figure 3. 95th percentile of maximum daily air temperature in degrees Celsius in the June-September period from 1978 to 2012 . Circle points mean a significant increase $(p$ value $<0.05)$ in the annual number of days with an air temperature higher than the 95 th percentile at $850 \mathrm{hPa}$ in the June-September period from 1978 to 2012. Triangle points mean that there were no significant changes.

the repercussions of extreme temperatures. It is important to consider the relative increase in extreme-temperature days at these higher latitudes, as a greater degree of change usually equates to a higher severity of challenge. Some authors suggest that the consequences of heat waves is closely tied to a culture's prior conditioning and adaptation to climate, including behavior (e.g., a siesta on hot afternoons), characteristics of buildings (e.g., exterior sun shades) and communities (orientation of windows away from afternoon sunlight), and even social attitudes about health risks (Poumadere et al., 2005; deCastro et al., 2011). This suggests that, although the absolute increase in extreme-temperature days is less severe at the higher latitudes, the relevance of the effects of the change may be greater in more northern populations lacking prior conditioning and adaptation.

In all cases, where HTD 95 increased, additional synergistic repercussions are likely to already be occurring. For example, Diffenbaugh et al. (2007) use downscaled climate model predictions of heat stress in the Mediterranean region to show that increases in 95th percentile maximum temperatures are amplified by a reduction in soil moisture and $2 \mathrm{~m}$ relative humidity levels. These changes are relevant to human health, wildfire risk, energy demand, and perpetuity of existing ecological systems.

\section{Implications and recommendations}

Implications of these results are far-ranging and diverse. Previous research shows that human mortality increases when maximum daily temperatures exceed a given threshold (García-Herrera et al., 2005; deCastro et al., 2011). In France alone in 2003, 15000 excess deaths were attributed to an extreme heat wave (Poumadère et al., 2005). If the annual number of extreme-temperature days continues to increase, as suggested by our data, mortality rates could respondsimilarly in the future. It may be necessary to take preventive measures to reduce these impacts on populations, preventing heat strokes and other heat-related illnesses. Such measures typically include increased cooling during these periods, which can also result in peak demands for energy consumption.

Energy demand is closely linked to climatic conditions (Giannakopoulos and Psiloglou, 2006). In the Mediterranean region, from mid-May onwards and during the summer period, an increase in air temperature aligns with a rise in energy consumption, mainly due to the wide use of air conditioning elements. It is during these early summer months that our data suggest that an increased number of HTDs will have the greatest impact on energy demands, especially in coastal Mediterranean areas. Higher temperatures in the summer are likely to cause a larger peak energy demand and not only an increase on net demand. This may require the development of additional, or more efficient, energy generating capacity.

Frequent heat waves in the last decade or so (2000-2012) have also triggered the occurrence of large wildland fires (Mills, 2005; Trigo et al., 2006; Barriopedro et al., 2011; Cardil et al., 2013) in the Euro-Mediterranean region. On hot days, ignition probability is higher and wildland fire behavior is typically more extreme. As a result, fires may be difficult to contain as they exceed the firefighting capabilities (Riaño et al., 2007; Salis et al., 2012; Cardil and Molina-Terren, 2013). Recent analysis has shown that high-temperatures days account for the majority of area burned in wildfires in some regions in Spain and Italy, where the average daily number of large fires and daily area burned was higher during HTDs than in non-HTDs (Cardil et al., 2013, 2014). Therefore, if extreme conditions (i.e., HTDs) are becoming more frequent, as our data suggest, forest fire risk and area burned will most likely increase.

The resilience of forests to disturbance may also be influenced by extreme temperatures. Touchan et al. (2014) 

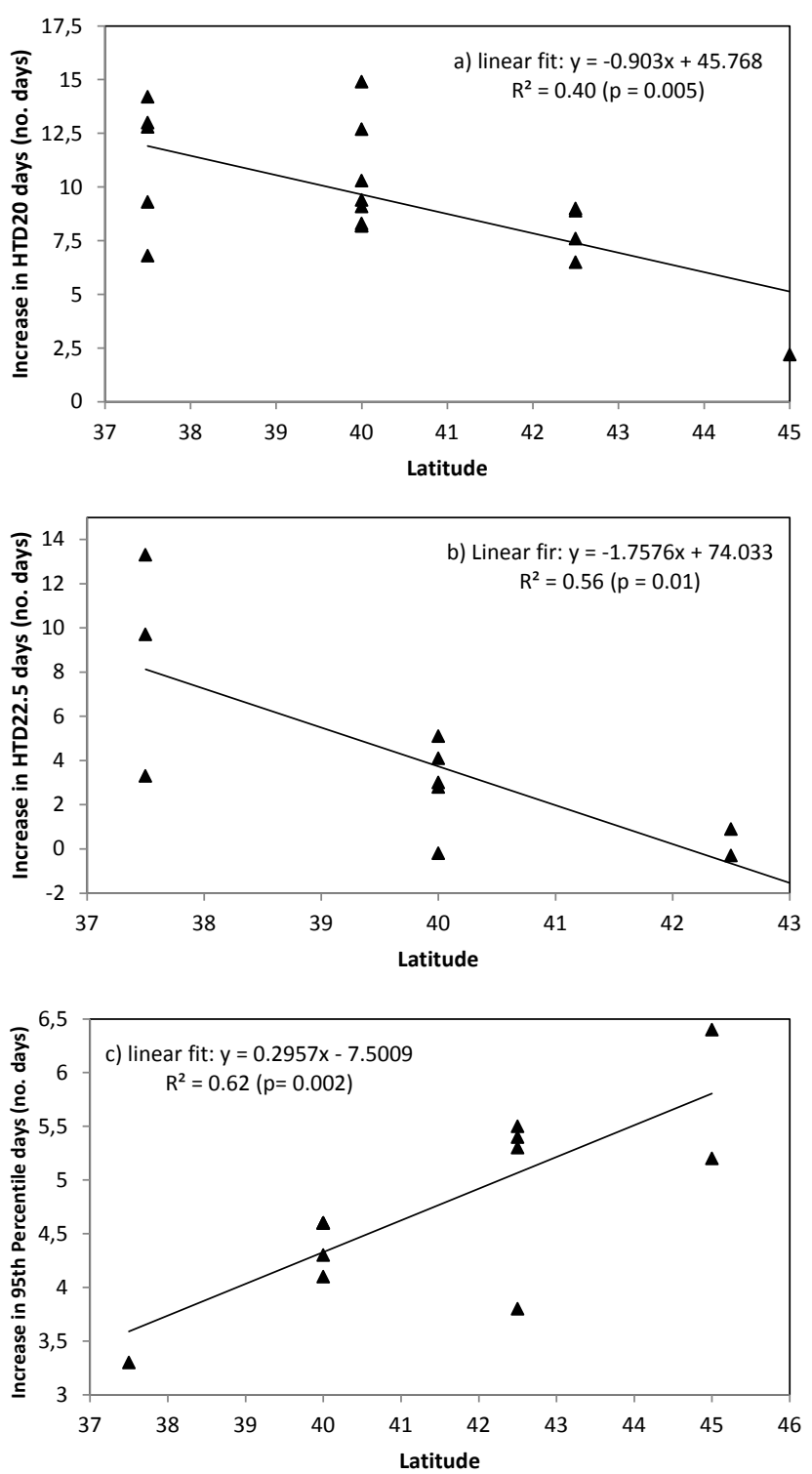

Figure 4. Linear regression showing the relationship between latitude and the change in the number of days with an air temperature at $850 \mathrm{hPa}$ higher than (a) $20^{\circ} \mathrm{C}\left(\mathrm{HTD}_{20}\right)$, (b) $22.5^{\circ} \mathrm{C}\left(\mathrm{HTD}_{22.5}\right)$, and (c) the 95th percentile at $850 \mathrm{hPa}$ in the June-September period from 1978 to 2012. The analysis included only sites where significant temporal changes were identified.

analyzed long-term tree chronologies in the eastern Mediterranean to find that growth rates were sensitive to, and negatively related to, summer month temperatures. The trends reported here suggest that, in certain areas, forests have been increasingly stressed by extreme temperatures during the summer months over the last 34 years. Evidence of such stress has been documented in increased climatelinked mortality of forests across Europe (Allen et al., 2010). As summertemperatures continue to increase (Giorgi and Lionello, 2008) and soil moisture contents decrease
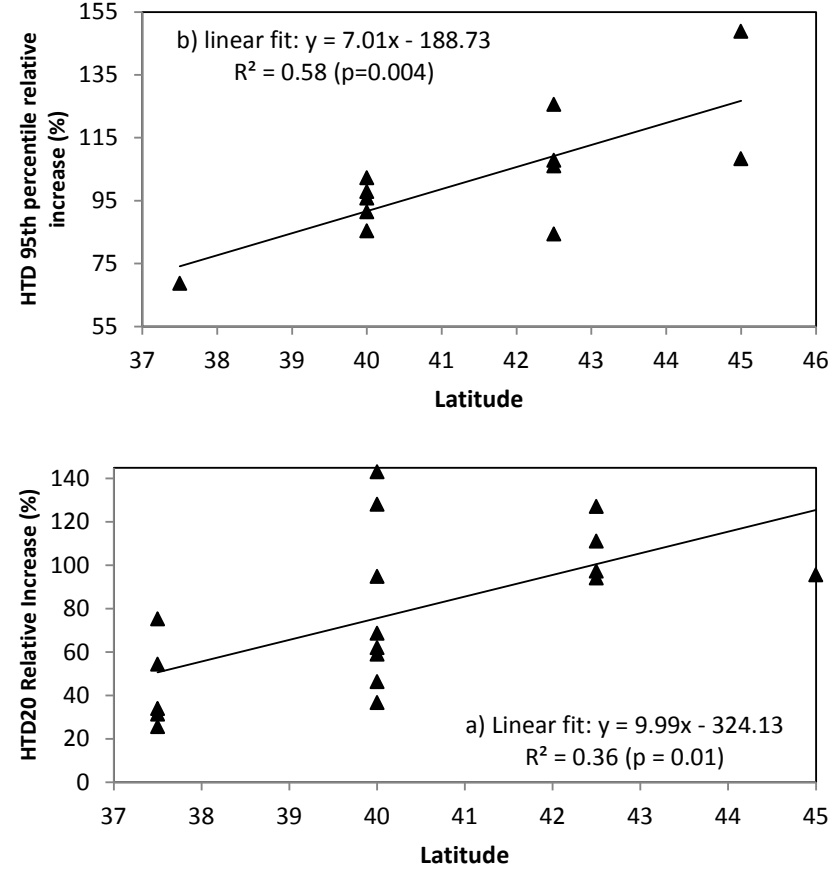

Figure 5. Linear regression testing relationship between latitude and percent change (relative increase) in the number of days with an air temperature at $850 \mathrm{hPa}$ higher than (a) $20^{\circ} \mathrm{C}\left(\mathrm{HTD}_{20}\right)$ and (b) exceeding the 95 th percentile at $850 \mathrm{hPa}$ in the June-September period from 1978 to 2012 . Only sites where significant temporal changes were identified were included in the analysis. HTD $_{22.5}$ did not change consistently with latitude.

(Diffenbaugh et al., 2007), the resilience of forests injured by wildfire may be reduced (e.g., van Mantgem et al., 2013), compounding wildfire impacts and costs to local economies.

Extreme-temperature events will also have impacts on industrial sectors with close links to climate, such as agriculture and food security. A diversity of research publications since 2010 shows that increased probability of extreme temperatures during the growing period has had deleterious impacts on agriculture (Gobin et al., 2013). Our data provide quantification of these extreme temperatures, which can be informative for agricultural planning and decision-making, specifically in each location analyzed.

Risk management should be active in anticipating potential problems and planning to mitigate their consequences, rather than reacting to unfavorable events after they happen. Both structural and non-structural measures are vital to reducing the impact of climate unevenness, including extreme weather events (Lobell et al., 2011). Structural actions include strategies, such as irrigation, water harvesting, creation of fuel breaks, and improved wildfire suppression, while the non-structural measures include the practice of medium range weather forecasting and developing new protective infrastructure, such as wildfire risk and crop insurance. We hope that the data presented here can be useful 
Table 2. Increase from 1978-1987 to 2002-2012 decades in both number of days and relative increase in number of days of HTD 20 , $\mathrm{HTD}_{22.5}$, and the 95th percentile (June-September period).

\begin{tabular}{|c|c|c|c|c|c|}
\hline Point & $\begin{array}{l}\text { Latitude/ } \\
\text { longitude }\end{array}$ & Country & $\begin{array}{l}\text { Increase of } \\
\text { days/relative } \\
\text { increase }(\%) \\
\text { HTD }_{20}\end{array}$ & $\begin{array}{l}\text { Increase of } \\
\text { days/relative } \\
\text { increase }(\%) \\
\text { HTD }_{22.5}\end{array}$ & $\begin{array}{l}\text { Increase of } \\
\text { days/relative } \\
\text { increase }(\%) \\
\text { HTD 95th } \\
\text { percentile }\end{array}$ \\
\hline 1 & $37.5^{\circ} / 352.5^{\circ}$ & Portugal & $5.3 / 19.1$ & $6.4 / 85.3$ & $3.5 / 85.4$ \\
\hline 2 & $37.5^{\circ} / 355^{\circ}$ & Spain & $9.2 / 25.5$ & $7.1 / 61.7$ & $1.9 / 40.4$ \\
\hline 3 & $37.5^{\circ} / 357.5^{\circ}$ & Spain & $14.2 / 31.4$ & $9.7 / 58.1$ & $3.1 / 68.9$ \\
\hline 4 & $37.5^{\circ} / 0^{\circ}$ & Spain & $13.0 / 25.6$ & $13.3 / 58.6$ & $2.9 / 58$ \\
\hline 5 & $40^{\circ} / 352.5^{\circ}$ & Portugal & $4.8 / 35.8$ & $3.4 / 178.9$ & $12.8 / 108.8$ \\
\hline 6 & $40^{\circ} / 355^{\circ}$ & Spain & $4.9 / 32.5$ & $0.9 / 30.0$ & $2.2 / 55$ \\
\hline 7 & $40^{\circ} / 357.5^{\circ}$ & Spain & $7.5 / 42.9$ & $1.1 / 22.5$ & $1 / 18.9$ \\
\hline 8 & $40^{\circ} / 0^{\circ}$ & Spain & $12.7 / 62.0$ & $2.8 / 41.8$ & $1.7 / 29.8$ \\
\hline 9 & $40^{\circ} / 2.5^{\circ}$ & Spain & $14.9 / 68.7$ & $5.1 / 68.9$ & $1.7 / 30.9$ \\
\hline 10 & $42.5^{\circ} / 352.5^{\circ}$ & Spain & $2.1 / 31.8$ & $0.9 / 75.0$ & $1.9 / 45.2$ \\
\hline 11 & $42.5^{\circ} / 355^{\circ}$ & Spain & $1.9 / 27.5$ & $1.0 / 71.4$ & $1.8 / 40.9$ \\
\hline 12 & $42.5^{\circ} / 357.5^{\circ}$ & Spain & $2.9 / 45.3$ & $0.7 / 41.2$ & $2.5 / 54.3$ \\
\hline 13 & $42.5^{\circ} / 0^{\circ}$ & Spain & $4.0 / 53.3$ & $0.7 / 33.3$ & $3.8 / 84.4$ \\
\hline 14 & $42.5^{\circ} / 2.5^{\circ}$ & Spain & $6.5 / 94.2$ & $0.4 / 16.7$ & $3.1 / 63.3$ \\
\hline 15 & $45^{\circ} / 0^{\circ}$ & France & $1.6 / 51.6$ & $0.8 / 88.9$ & $2.4 / 47.1$ \\
\hline 16 & $45^{\circ} / 2.5^{\circ}$ & France & $2.3 / 74.2$ & $0.7 / 77.8$ & $3.8 / 82.6$ \\
\hline 17 & $45^{\circ} / 5^{\circ}$ & France & $2.9 / 93.5$ & $0.5 / 83.3$ & $3.7 / 74$ \\
\hline 18 & $45^{\circ} / 7.5^{\circ}$ & France & $2.4 / 88.9$ & $2.4 / 12.4$ & $4.3 / 91.5$ \\
\hline 19 & $37.5^{\circ} / 12.5^{\circ}$ & Italy & $4.3 / 10.9$ & $3.0 / 19.6$ & $0.6 / 9.8$ \\
\hline 20 & $37.5^{\circ} / 15^{\circ}$ & Italy & $3.9 / 11.7$ & $4.4 / 53.0$ & $1.3 / 22.4$ \\
\hline 21 & $40^{\circ} / 10^{\circ}$ & Italy & $8.3 / 36.7$ & $4.1 / 66.1$ & $2.9 / 53.7$ \\
\hline 22 & $40^{\circ} / 15^{\circ}$ & Italy & $8.2 / 46.3$ & $4.1 / 107.9$ & $4.6 / 95.8$ \\
\hline 23 & $40^{\circ} / 17.5^{\circ}$ & Italy & $8.2 / 59.0$ & $-0.2 /-9.5$ & $4.1 / 85.4$ \\
\hline 24 & $42.5^{\circ} / 10^{\circ}$ & Italy & 7.6/97.4 & $0.5 / 22.7$ & $5.5 / 107.8$ \\
\hline 25 & $42.5^{\circ} / 12.5^{\circ}$ & Italy & $9.0 / 111.1$ & $1.9 / 111.8$ & $5.3 / 106$ \\
\hline 26 & $42.5^{\circ} / 15^{\circ}$ & Italy & $8.9 / 127.1$ & $-0.3 /-60$ & $5.4 / 125.6$ \\
\hline 27 & $45^{\circ} / 10^{\circ}$ & Italy & $1.8 / 66.7$ & $-0.3 /-60$ & $6.4 / 148.8$ \\
\hline 28 & $45^{\circ} / 12.5^{\circ}$ & Italy & $2.2 / 95.6$ & $-0.3 /-75$ & $5.2 / 108.3$ \\
\hline 29 & $37.5^{\circ} / 20^{\circ}$ & Greece & $6.8 / 34.0$ & $2.9 / 40.3$ & $1.6 / 27.1$ \\
\hline 30 & $37.5^{\circ} / 22.5^{\circ}$ & Greece & $9.3 / 54.4$ & $2.2 / 34.9$ & $2.2 / 39.3$ \\
\hline 31 & $37.5^{\circ} / 25^{\circ}$ & Greece & $12.8 / 75.3$ & $3.3 / 61.1$ & $3.3 / 68.8$ \\
\hline 32 & $40^{\circ} / 20^{\circ}$ & Greece & $9.4 / 94.9$ & $3.0 / 107.1$ & $4.6 / 102.2$ \\
\hline 33 & $40^{\circ} / 22.5^{\circ}$ & Greece & $10.3 / 143.1$ & $1.8 / 75.0$ & $4.3 / 91.5$ \\
\hline 34 & $40^{\circ} / 25^{\circ}$ & Greece & $9.1 / 128.2$ & $1.5 / 75.0$ & $4.6 / 97.9$ \\
\hline
\end{tabular}

for planning for risk reduction across the multiple sectors affected by increases in high-temperature days in Europe.

\section{Conclusions}

Even though we did not find significant increases in the south of France, interior Spain and the northwestern Iberian Peninsula, the annual number of HTDs increased significantly in many areas across southern Europe, including the Spanish Mediterranean Coast, Italy, and Greece. The highest increases in terms of annual number of HTDs were found in both Greece and along the Spanish Mediterranean Coast. In these areas, extreme-temperature conditions are becoming more frequent now and could become more common in the future. In addition, in areas where temporal increases were detected, relative increases in 95th percentile temperatures were larger at higher latitudes. Where social, infrastructure, and economic systems are not preconditioned to high-temperature days and heat waves, the severity of increased temperature effects may be elevated. Heat-wave days have been linked to negative impacts in terms of forest fire risk, human health, agriculture, energy demands, and economic repercussions. Adaptive measures should be taken for reducing the negative consequences for human populations and the environment. 
Acknowledgements. We are appreciative to the University of Lleida and Pau Costa Foundation for supporting this study through a partial grant to fund Adrian Cardil PhD studies. We also thank the Erasmus Mundus European Forestry program for supporting international scholarly collaboration on topics with relevance to the forestry profession across Europe.

Edited by: R. Lasaponara

Reviewed by: two anonymous referees

\section{References}

Allen, C. D., Macalady, A. K., Chenchouni, H., Bachelet, D., McDowelle, N., Vennetier, M., Kitzberger, T., Rigling, A., Breshears, D. D., Hogg, E. H., Gonzalez, P., Fensham, R., Zhang, Z., Castro, J., Demidova, N., Lim, J.-H., Allard, G., Running, S. W., Semerci, A., and Cobb, N.: A global overview of drought and heat-induced tree mortality reveals emerging climate change risks for forests, Forest Ecol. Manage., 259, 660-684, 2010.

Barriopedro, D., Fischer, E. M., Luterbacher, J., Trigo, R. M., and García-Herrera, R.: The Hot Summer of 2010: Redrawing the Temperature Record Map of Europe, Science, 332, 220-224, 2011.

Cardil, A. and Molina-Terren, D. M.: Large wildland fires in three diverse regions in Spain from 1978 to 2010, Forest Systems, 22, 526-534, 2013.

Cardil, A., Molina, D. M., Ramirez, J., and Vega-García, C.: Trends in adverse weather patterns and large wildland fires in Aragón (NE Spain) from 1978 to 2010, Nat. Hazards Earth Syst. Sci., 13, 1393-1399, doi:10.5194/nhess-13-1393-2013, 2013.

Cardil, A., Salis, M., Spano, D., Delogu, G., and Molina, D. M.: Large wildland fires and extreme temperatures in Sardinia (Italy), iForest, 7, 162-169, doi:10.3832/ifor1090-007, 2014.

deCastro, M., Gómez-Gesteira, M., Ramos, A. M., Alvarez, I., and deCastro, P.: Effects of heat waves on human mortality, Galicia, Spain, Clim. Res., 48, 333-341, 2011.

Diffenbaugh, N. S., Pal, J. S., Giorgi, F., and Gao, X.: Heat stress intensification in the Mediterranean climate change hotspot, Geophys. Res. Lett., 34, L11706, doi:10.1029/2007GL030000, 2007.

García-Herrera, R., Díaz, J., Trigo, R. M., and Hernández, E.: Extreme summer temperatures in Iberia: health impacts and associated synoptic conditions, Ann. Geophys., 23, 239-251, doi:10.5194/angeo-23-239-2005, 2005.

García-Ortega, E., Trobajo, M. T., López, L., and Sánchez, J. L.: Synoptic patterns associated with wildfires caused by lightning in Castile and Leon, Spain, Nat. Hazards Earth Syst. Sci., 11, 851-863, doi:10.5194/nhess-11-851-2011, 2011.

Giannakopoulos, C. and Psiloglou, B. E.: Trends in energy load demand for Athens, Greece: weather and non-weather related factors, Clim. Res., 31, 97-108, 2006.

Giannakopoulos, C., Le Sager, P., Bindi, M., Moriondo, M., Kostopoulou, E., and Goodess, C. M.: Climatic changes and associated impacts in the Mediterranean resulting from a $2{ }^{\circ} \mathrm{C}$ global warming, Global Planet. Change, 68, 209-224, 2009.

Giorgi. F.: Climate change hot-spots, Geophys. Res. Lett., 33, L08707, doi:10.1029/2006GL025734, 2006.

Giorgi, F. and Lionello, P.: Climate change projections for the Mediterranean region, Global Planet. Change, 63, 90-104, 2008.
Gobin, A., Tarquis, A. M., and Dalezios, N. R.: Preface "Weatherrelated hazards and risks in agriculture", Nat. Hazards Earth Syst. Sci., 13, 2599-2603, 2013,

http://www.nat-hazards-earth-syst-sci.net/13/2599/2013/.

Gomez-Gesteira, M., Gimeno, L., deCastro, M., Lorenzo, M. N., Alvarez, I., Nieto, R., Taboada, J. J., Crespo, A. J. C., Ramos, A. M., Iglesias, I., Gómez-Gesteira, J. L., Santo, F. E., Barriopedro, D., and Trigo, I. F.: The state of climate in NW Iberia, Clim. Res., 48, 109-144, 2011.

IPCC: IPCC Fourth Assessment Report: Climatic Change 2007, available at: http://www.ipcc.ch/ipccreports/ assessments-reports.htm (last access: 5 March 2014), 2007.

Kalnay, E., Kanamitsu, M., Kistler, R., Collins, W., Deaven, D., Gandin, L., Iredell, M., Saha, S., White, G., Woollen, J., Zhu, Y., Leetmaa, A., and Reynolds, R.: The NCEP/NCAR 40-year reanalysis project, B. Am. Meteorol. Soc., 77, 437-471, 1996.

Kuglitsch, F. G., Toreti, A., Xoplaki, E., Della-Marta, P. M., Zerefos, C. S., Türkeş, M., and Luterbacher, J.: Heat wave changes in the eastern Mediterranean since 1960, Geophys. Res. Lett., 37, L04802, doi:10.1029/2009GL041841, 2010.

Lobell, D. B., Schlenker, W., and Costa-Roberts, J.: Climate Trends and Global Crop Production Since 1980, Science, 333, 616-620, 2011.

Luterbacher, J., Dietrich, D., Xoplaki, E., Grosjean, M., and Wanner, H.: European seasonal and annual temperature variability, trends, and extremes since 1500, Science, 303, 1499-1503, 2004.

Mills, G. A.: A re-examination of the synoptic and mesoscale meteorology of Ash Wednesday 1983, Aust. Meteorol. Mag., 54, 35-55, 2005.

Montserrat, D.: Situaciones sinópticas relacionadas con el inicio de grandes incendios forestales en Cataluña, Nimbus, 1-2, 93-112, 1998.

Moriondo, M., Good, P., Durao, R., Bindi, M., Giannakopoulos, C., and Corte-Real, J.: Potential impact of climate change on fire risk in the Mediterranean area, Clim. Res., 31, 85-95, 2006.

Ogi, M., Yamazaki, K., and Tachibana, Y.: The summer northern annular mode and abnormal summer weather in 2003, Geophys. Res. Lett., 32, L04706, doi:10.1029/2004GL021528, 2005.

Pereira, M. G., Malamud, B. D., Trigo, R. M., and Alves, P. I.: The history and characteristics of the 1980-2005 Portuguese rural fire database, Nat. Hazards Earth Syst. Sci., 11, 3343-3358, doi:10.5194/nhess-11-3343-2011, 2011.

Poumadère, M., Mays, C., Le Mer, S., and Blong, R.: The 2003 Heat Wave in France: Dangerous Climate Change Here and Now, Risk Anal., 25, 1483-1494, 2005.

Regato, P.: Adapting to global change: Mediterranean forests, IUCN Centre for Mediterranean Cooperation, Malaga, Spain, 254 pp, 2008.

Riaño, D., Ruiz, J. A., Isidoro, D., and Ustin, S. L.: Global spatial patterns and temporal trends of burned area between 1981 and 2000 using NOAA-NASA Pathfinder, Global Change Biol., 13, 40-50, 2007

Rodriguez-Puebla C., Encinas, A. H., García-Casado, L. A., and Nieto, S.: Trends in warm days and cold nights over the Iberian Peninsula: relationships to large-scale variables, Climatic Change, 100, 667-684, 2010.

Safranyik, L.: Mountain pine beetle epidemiology in lodgepole pine. Canadian Forest Service, Pacific Forestry Centre, Information Report BC-X-399, Victoria, BC, p. 298, 2004. 
Salis, M., Ager, A. A., Arca, B., Finney, M. A., Bacciu, V., Duce, P., and Spano, D.: Assessing exposure of human and ecological values to wildfire in Sardinia, Italy. Int. J. Wildland Fire, 22, 549-565, 2012.

Touchan, R., Anchukaitis, K. J., Shishov, V. V., Sivrikaya, F., Attieh, J., Ketmen, M., Stephan, J., Mitsopoulos, I., Christou, A., and Meko, D. M.: Spatial Patterns of Eastern Mediterranean Climate Influence on Tree Growth, Holocene, 24, 381-392, 2014.

Trigo, R. M., García-Herrera, R., Díaz, J., Trigo, I. F., and Valente, M. A.: How exceptional was the early August 2003 heatwave in France?, Geophys. Res. Lett., 32, L10701, doi:10.1029/2005GL022410, 2005.
Trigo, R. M., Pereira, J. M., Mota, B., Calado, T., Dacamara, C., and Santo, F.: Atmospheric conditions associated with the exceptional fire season of 2003 in Portugal, Int. J. Climatol., 26, 1741-1757, 2006.

van Mantgem, P. J., Nesmith, J. C. B., Keifer, M., Knapp, E. E., Flint, A., and Flint, L.: Climatic stress increases forest fire severity across the western United States, Ecol. Lett., 16, 1151-1156, 2013. 